\title{
Adam Kucharski
}

Instytut Historii i Archiwistyki, Uniwersytet Mikołaja Kopernika w Toruniu

e-mail: akr88@umk.pl

\section{ośrednictwo Jakuba Kazimierza}

\section{Rubinkowskiego w konserwacji i zakupie}

\section{książek dla Elżbiety Sieniawskiej w latach}

\section{$1725-1726$}

Dr hab. Adam Kucharski jest pracownikiem naukowym Instytutu Historii i Archiwistyki Uniwersytetu Mikołaja Kopernika w Toruniu. Zajmuje się podróżnictwem w epoce nowożytnej, mobilnością społeczeństwa staropolskiego, wrażliwością estetyczną społeczeństwa polskiego w XVI-XVIII wieku, staropolskim obrazem świata oraz polsko-hiszpańskimi kontaktami kulturalnymi w epoce nowożytnej. Do ważniejszych publikacji należą: Hiszpania i Hiszpanie w relacjach Polaków (Warszawa 2007) oraz Theatrum peregrinandi. Poznawcze aspekty staropolskich podróży w epoce późnego baroku (Toruń 2013). W ramach popularyzacji nauki współpracował z Muzeum Pałacu Króla Jana III w Wilanowie (projekt „Silva rerum”) oraz redakcją „Wiadomości Historycznych”.

łowa kluczowe: Jakub Rubinkowski, Elżbieta Sieniawska, książka, introligatorstwo, Toruń

treszczenie. Wielowymiarowa działalność toruńskiego rajcy i poczmistrza królewskiego Jakuba Kazimierza Rubinkowskiego zorientowana była głównie na prowadzenie agencji informacyjnej zajmującej się redagowaniem i kolportażem prasy rękopiśmiennej. Ważnym aspektem jego aktywności kulturalnej stało się również pośredniczenie w załatwianiu usług introligatorskich i kupnie książek dla hetmanowej wielkiej koronnej i kasztelanowej krakowskiej Elżbiety Sieniawskiej. Rubinkowski, szlachcic, a zarazem barokowy erudyta i zapalony bibliofil, był idealnym kandydatem do realizacji tych zadań. O jego przydatności decydowała silna pozycja Torunia na polskim rynku księgarskim gwarantująca możliwość nabywania poszukiwanych tomów ksiąg, zarówno krajowych, jak i zagranicznych autorów. Kwerenda księgarska obejmowała dzieła ojca Sieniawskiej, Stanisława Herakliusza Lubomirskiego, innych autorów polskich (również z obszaru Prus Królewskich), a także klasyków nowożytnej literatury europejskiej. Niemniej ważnym atutem Rubinkowskiego była również możliwość bezpośredniego kontaktu z toruńskim cechem mistrzów introligatorskich, co zapewniało Sieniawskiej sprawny proceder konserwacji i renowacji ksiąg, pochodzących głównie z jej biblioteki w Puławach. Rubinkowski, szczególnie w latach 1725-1726, wielokrotnie i skrupulatnie informował o zbliżających się aukcjach książek organizowanych w Toruniu, przyjmował księgi ekspediowane statkami z Puław oraz organizował transport powrotny zakupionych i odnowionych woluminów. W sumie w ciągu zaledwie dwóch lat przez jego ręce przewinęło się kilkaset książek, czyniąc go jednym z czołowych agentów księgarskich tego czasu w Rzeczypospolitej Obojga Narodów. 
W dziejach kultury Torunia początek XVIII w. charakteryzował się wzrostem poziomu rozwoju życia intelektualnego, a przez całe stulecie, mimo symptomów niewątpliwego kryzysu, miasto plasowało się w czołówce polskiego drukarstwa oraz pozostawało znaczącym ośrodkiem księgarskim ${ }^{1}$. Toruń utrzymywał ten status dzięki aktywności drukarzy, księgarzy, autorów książek czy introligatorów. Swoją rolę w procesie obrotu książkami mieli też do odegrania pośrednicy, do których możemy zaliczyć poczmistrza toruńskiego Jakuba Kazimierza Rubinkowskiego (1668-1749)2. W liczącym sobie około dwustu listów zbiorze jego korespondencji do Elżbiety Sieniawskiej ${ }^{3} z$ znajduje się szereg informacji odnośnie do intensywnych kontaktów księgarskich w drugiej dekadzie XVIII w. oraz w połowie lat 20. tego stulecia między Toruniem a Puławami. Celem tego opracowania będzie omówienie realizacji przez Rubinkowskiego zleceń Elżbiety Sieniawskiej w świetle zachowanych listów.

Korespondencja Jakuba Rubinkowskiego, toruńskiego patrycjusza, bibliofila i erudyty o znacznych ambicjach literackich, przynosi przede wszystkim szereg wiadomości na temat funkcjonowania jego agencji informacyjnej zarówno w aspekcie transferu najświeższych nowin, jak i politycznych prognoz ${ }^{4}$. Adresatką listów była kasztelanowa krakowska i hetmanowa wielka koronna Elżbieta Sieniawska z Lubomirskich (ok. 1669-1729), jedna z najbardziej aktywnych kobiet w ówczesnym polskim życiu politycznym, prowadząca rozległą korespondencję $z$ wieloma osobami ${ }^{5}$. Listy z dziesięciolecia 1716-1726 zawierają liczne informacje dotyczące zakupów ksiąg na licytacjach toruńskich księgozbiorów, poszukiwania cennych i rzadkich tytułów, a przede wszystkim oprawiania i konserwacji zniszczonych egzemplarzy. Pojedyncze listy Rubinkowskiego, które nie weszły do cytowanego powyżej zbioru jego korespondencji, znajdują się także w innych zespołach rękopisów ${ }^{6}$. $Z$ treści listów wynika, że kontrakt na usługi pocztowo-księgarskie Rubinkowski zawarł z Sieniawską w $1717 \mathrm{r}^{7}$

Analiza zachowanej korespondencji wskazuje, że w pierwszych listach pochodzących z najwcześniejszego okresu współpracy, a w zasadzie służby Rubinkowskiego, co sam nieustannie podkreślał, jawi się on jako dostarczyciel informacji gazetowych o sytuacji politycznej i wojskowej w kraju oraz regionie ${ }^{8}$. W tym okresie powiadamiał o stanie realizacji zleceń gdańskich przez faktorów handlowych oraz sam zamawiał niektóre towary z bardziej egzotycznego asor-

\footnotetext{
S. Salmonowicz, Dzieje książki i czytelnictwa, [w:] Historia Torunia, red. M. Biskup, t. II, cz. III: Między barokiem a oświeceniem (1660-1793), Toruń 1996, s. 372.

2 Szerzej na jego temat zob. K. Maliszewski, Jakub Kazimierz Rubinkowski. Szlachcic, mieszczanin toruński, erudyta barokowy, Warszawa-Poznań-Toruń 1982.

3 Autografy listów Rubinkowskiego, zebranych w oprawnej księdze, znajdują się w zasobie zbiorów rękopiśmiennych Biblioteki Czartoryskich w Krakowie (dalej BCz), rkps 5933/IV, nr 34364-34549.

4 K. Maliszewski, Agencja informacyjna Jakuba Kazimierza Rubinkowskiego. Ze studiów nad dziejami komunikacji społecznej w XVIII wieku, Zapiski Historyczne, t. 48: 1983, s. 49-69.

5 Zob. B. Popiołek, Królowa bez korony. Studium z życia i działalności Elżbiety Sieniawskiej (ok. 1669-1729), Kraków 1993; A. Słaby, Rządzicha oleszycka. Dwór Elżbiety z Lubomirskich Sieniawskiej jako przykład patronatu kobiecego w czasach saskich, Kraków 2014.

$6 \quad$ BCz, rkps 1684, 2707, 2739, 2747.

7 B. Popiołek, Zainteresowania bibliofilskie Elżbiety z Lubomirskich Sieniawskiej, kasztelanowej krakowskiej, Rocznik Naukowo-Dydaktyczny WSP w Krakowie, 1995, Prace Historyczne XVII, z. 167, s. 48.

8 BCz, rkps 5933, nr 34366, J. Rubinkowski do E. Sieniawskiej 15 III 1717 r. z Torunia.
} 
tymentu (np. portugalskie pomarańcze). Przesyłał również Sieniawskiej różne prezenty, np. smakowite wiktuały (pierniki oraz drozdy). Podarunki przeplatały się z prośbami o uregulowanie zaległej zapłaty za wykonane usługi. Informował również o fluktuacji cen na rynku zbożowym, pisząc, jakie ceny dyktują „targi zboża we Gdańsku". Usługi doręczania najnowszych wiadomości, świadczone Sieniawskiej, były tylko częścią szerszej działalności prasowej Rubinkowskiego, który od 1716 r. własnoręcznie redagował i rozsyłał gazety, korzystając z sieci połączeń pocztowych, do różnych adresatów (byli to m.in. kanclerz wielki koronny Jan Szembek, Radziwiłłowie, Sanguszkowie, Mniszchowie), kreując w ten sposób rolę Torunia jako ważnego ośrodka transferu informacji ${ }^{9}$.

Niezmiernie istotnym, wręcz fundamentalnym filarem procesów komunikacji społecznej, obecnych w kulturze staropolskiej, były zarówno druk, jak i rękopis, prasa rękopiśmienna i książka ${ }^{10}$. Te dwa główne nośniki informacji i wiedzy ujawniły się w działalności Jakuba Rubinkowskiego, który oprócz gazet rękopiśmiennych wysyłał także różnego typu druki. Z jego korespondencji wynika, że w początkowej fazie współpracy z Sieniawską były to głównie drukowane wydawnictwa niewielkiej objętości, przede wszystkim zaś kalendarze. Jesienią $1717 \mathrm{r}$. informował o wysłaniu kalendarza autorstwa brandenburskiego matematyka na rok następny. Szczególnie interesujące były dla adresatki charakterystyczne dla barokowej mentalności curiositates oraz polonika zawarte w tym wydawnictwie ${ }^{11}$. Kalendarze jako wydawnictwa typu informacyjno-prognostycznego cieszyły się wówczas wielkim powodzeniem u czytelników. W 1718 r. Rubinkowski przesłał Elżbiecie Sieniawskiej „klucz do kalendarza angielskiego”12. Ta enigmatyczna nazwa oznaczała zapewne jakąś formę tłumaczenia polskiego. Znamy bowiem zamieszczone $w$ listach $z$ tego samego roku także inne wzmianki o wysłaniu przekładu na język rodzimy angielskiego zbioru przepowiedni na bieżący rok, wydrukowanego w Londynie. Przesłanie angielskiego prognostyku poczmistrz toruński tłumaczył brakiem analogicznych druków krajowych: „gdyż pruscy astronomowie cale teraz pole zależeli i nic na ten rok nie wydali"13. Na przełomie lat 1719/1720 zakupił i wysłał, jako realizację wcześniejszego zamówienia, obrazy czterech ewangelistów: „tak wielkiej estymy jako być lepsze nie mogą i kto ich tylko wiedzieć może, nie może się tak konsztownej napatrzeć robocie, a są świżo malowane, nie zabrukane" (ostatecznie przesłane pocztą dnia 3 lutego 1720 r.). Ekspediując je, prosił o przesłanie karabeli14. Zachwalał te obrazy pochodzące z Antwerpii jako idealny element wyposażenia kościoła: „Ceny nie piszę. Jak ich

\footnotetext{
9 S. Salmonowicz, Toruń w czasach baroku i oświecenia. Szkice z dziejów kultury Torunia XVII-XVIII wieku, Warszawa-Poznań-Toruń 1982, s. 122.

10 K. Maliszewski, Komunikacja społeczna w kulturze staropolskiej. Studia z dziejów kształtowania się form i treści społecznego przekazu w Rzeczypospolitej szlacheckiej, Toruń 2001, s. 15, 18, 20-21.

11 BCz, rkps 5933, nr 34377, J. Rubinkowski do E. Sieniawskiej 6 IX 1717 r. z Torunia.

12 BCz, rkps 5933, nr 34388, J. Rubinkowski do E. Sieniawskiej 18 IV 1718 r. z Torunia.

${ }^{13} \mathrm{BCz}$, rkps 2707, s. 323, J. Rubinkowski do E. Sieniawskiej 28 II 1718 r. z Torunia.

${ }_{14}$ BCz, rkps 5933, nr 34405, J. Rubinkowski do E. Sieniawskiej 18 XII 1719 r. z Torunia; BCz, rkps 5933, nr 34407, J. Rubinkowski do E. Sieniawskiej 3 II 1720 r. z Torunia.
} 
sama WXMść Dobrodziejka osądzisz najmniejszą ceną kontentować się za nie będę"15.

Jakub Rubinkowski realizował swoją strategię informacyjną, przesyłając Sieniawskiej także oryginalne dokumenty objaśniające bieżącą sytuację w kraju. W roku 1724 Toruń stanął w centrum uwagi wszystkich krajowych środków przekazu za sprawą kontrowersyjnych zajść wyznaniowych nazwanych Tumultem Toruńskim. Różnorodnie oceniany w Europie, natomiast przez Rubinkowskiego przedstawiony jako słuszny akt protestu strony katolickiej przeciwko ograniczaniu wolności kultu w mieście. W liście z połowy roku donosił on o innowierczej rebelii i „zniszczeniu” kolegium jezuickiego przez protestantów oraz załączał kopię listu toruńskich jezuitów do króla, w którym - jak pisał - „malicyją dysydentów raczysz wyczytać Jaśnie Oświecona Waszmość Dobrodziejka"16. Były to najświeższe wiadomości pochodzące bezpośrednio z areny wydarzeń, dzięki czemu Rubinkowski włączył się aktywnie w proces informowania o przebiegu tumultu, który opisywany był w szeregu druków ukazujących się od połowy 1724 r. ${ }^{17}$ Ton tego listu kreował go już wyraźnie na zdeklarowanego obrońcę praw i trybuna interesów katolickiej ludności Torunia, które zaczął wkrótce reprezentować jako jeden z czterech pierwszych katolickich rajców ${ }^{18}$. Pośrednio wspierał również polityczne działania Adama Mikołaja Sieniawskiego, przekazując jego listy do sejmiku brzesko-kujawskiego i dobrzyńskiego.

Należy w tym miejscu odnotować, że Rubinkowski był głównym, chociaż nie jedynym, współpracownikiem $w$ dziele uzupełniania i rozbudowy bibliotek należących do Sieniawskich. Oprócz niego powiększanie puławskiego księgozbioru zapewniały usługi kupca gdańskiego J. Nethlera oraz gdańskiej rodziny Tessynów. Sieniawska utrzymywała również bliskie kontakty z poetką Elżbietą Drużbacką ${ }^{19}$. Pierwsza dochowana wzmianka o poważniejszych księgarskich usługach Rubinkowskiego dla Sieniawskiej pochodzi jednak dopiero z końca 1721 r., gdyż wcześniejsze zlecenia dotyczyły głównie przesyłania kalendarzy. Informował wówczas o fiasku poszukiwań wydań „ksiąg Artaksesa z Evandrem jako i Tobiasza edycyi śp. nieboszczyka ojca WXMści”. Rubinkowski donosił, że kwerenda dzieł Stanisława Herakliusza Lubomirskiego w Toruniu i Gdańsku nie przyniosła żadnych rezultatów oraz doradzał wywiad wśród polskich bibliofilów ${ }^{20}$.

Ożywione pośrednictwo Rubinkowskiego w zakupie i konserwacji książek na zlecenie Sieniawskiej miało związek z intensyfikacją jej aktywności mecenasowskiej w zakresie kultury i sztuki. Szczególniejszym powodem była w tym względzie troska o bogaty księgozbiór rytwiański odziedziczony po przodku Sta-

15 BCz, rkps 5933, nr 34413, J. Rubinkowski do E. Sieniawskiej 8 I 1720 r. z Torunia.

16 BCz, rkps 5933, nr 34500, J. Rubinkowski do E. Sieniawskiej 24 VII 1724 r. z Torunia.

17 J. Milewska-Kozłowska, Druki dotyczące Tumultu Toruńskiego w zbiorach starych druków Biblioteki Uniwersytetu Mikołaja Kopernika w Toruniu, Rocznik Toruński, t. 34: 2007, s. 207-246.

18 K. Maliszewski, Rubinkowski Jakub Kazimierz, [w:] Polski Słownik Biograficzny (dalej: PSB), t. 32, Wrocław 1989, S. 568 .

19 A. K. Link-Lenczowski, B. Popiołek, Sieniawska z Lubomirskich Elżbieta Helena (1669-1729), [w:] PSB, t. 37, Warszawa-Kraków 1996-1997, s. 95.

20 BCz, rkps 5933, nr 34439, J. Rubinkowski do E. Sieniawskiej 29 XII 1721 r. z Torunia. 
nisławie Łukaszu Opalińskim. W posiadaniu Sieniawskich znajdowały się jeszcze dwa ważne księgozbiory, a mianowicie w Łubnicach, należący do Elżbiety i brzeżański - jej męża Adama Mikołaja Sieniawskiego ${ }^{21}$. Ważną kwestią w początkach XVIII w. stało się właśnie urządzenie biblioteki w pałacu Sieniawskich w Puławach. W 1706 r. klucz dóbr końskowolskich wszedł w posiadanie Elżbiety Sieniawskiej i jej męża Adama Sieniawskiego. W tym samym roku wojska szwedzkie spaliły jednak pałac puławski, niszcząc doszczętnie jego wyposażenie ${ }^{22}$. Biblioteki zajmowały szczególne miejsce w rezydencjach magnackich. Praktycznie od XVI w. ogromna większość budowanych lub restaurowanych kompleksów pałacowych otrzymywała bogato zdobione pomieszczenia przeznaczone do przechowywania księgozbiorów ${ }^{23}$. Zapewne podobnie było w przypadku Puław. Być może część książek pochodziła jeszcze ze spalonego pałacu i wymagała pilnej renowacji. Niewiele jednak wiadomo na temat restaurowania samego kompleksu pałacowego. W pierwszych latach po przejęciu pałacu został on jedynie zabezpieczony przed dalszymi zniszczeniami i to w nienajlepszym stopniu. W 1722 r. doszło do osunięcia się i popękania części murów podmytych przez nurt Wisły. Fakt ten nie zainicjował jednak odbudowy pałacu na większą skalę, a jedynie podjęto kolejne prace zabezpieczające dachy i okna. W celu przebudowy pałacu został zatrudniony architekt Jan Zygmunt Deybel, najprawdopodobniej w 1727 r. ${ }^{24}$ Plany rozbudowy i uświetnienia gmachu zostały więc wprowadzone w życie dopiero po ustaniu korespondencji między Rubinkowskim a Sieniawską. Być może książki, które Rubinkowski często opisuje jako „zgnojone”, uległy destrukcji wskutek wilgoci panującej w gmachu puławskiego pałacu.

Regularne noty o książkach kierowanych do oprawy i konserwacji u toruńskich introligatorów zaczynają pojawiać się w listach dopiero od wiosny 1725 $r^{25} \mathrm{~W}$ wielu listach Rubinkowski skarżył się na przedłużające się oczekiwanie na książki przewożone na pokładach statków Sieniawskich płynących do Gdańska. Co zrozumiałe, dużą uwagę przykładał do kwestii technicznych przesyłania książek. Nie wykorzystywał w tym celu dobrze rozwiniętej sieci lądowych połączeń pocztowych. W 1. połowie XVIII w. normą dla przewozów nielistowych było wynajmowanie zaprzęgów końskich ${ }^{26}$. Rubinkowski do przewozu ciężkich skrzyń z książkami posługiwał się jednak transportem wiślanym, wykorzystując do tego celu statki Sieniawskich płynące z ładunkiem zboża na północ. W drodze powrotnej książki ponownie umieszczano w skrzyniach i spławiano je w górę Wisły na statkach do Puław. W celu zabezpieczenia przed otwieraniem podczas rewizji w komorach celnych umieszczał na skrzyniach pieczęcie skarbowe. Dbał w ten sposób o kompletność przesyłek, które jednak nie zawsze docierały w całości.

\footnotetext{
21 B. Popiołek, Zainteresowania bibliofilskie..., s. 47.

22 M. Kseniak, Rezydencja Czartoryskich w Puławach, Lublin 1986, s. 5.

23 B. Bieńkowska, Staropolski świat książek, Wrocław 1976, s. 216-217.

24 I. Malinowska, Przebudowa pałacu w Puławach przez architekta Jana Zygmunta Deybla, [w:] Puławy, red. S. Lorentz, Teka Konserwatorska, z. 5, Warszawa 1962, s. 28.

25 BCz, rkps 5933, nr 34518, J. Rubinkowski do E. Sieniawskiej 30 III 1725 r. z Torunia.

26 L. Zimowski, Geneza i rozwój komunikacji pocztowej na ziemiach polskich, Warszawa 1972 , s. 88.
} 
W samych listach zdecydowanie dominuje matematyka księgarska. Można dowiedzieć się sporo o liczbie ksiąg przekazywanych do naprawy i cenach za usługi introligatorskie. Znajdują się tam również sporadyczne wzmianki na temat rodzaju oprawy, którą Rubinkowski reklamował jako kunsztowną i zaopatrzoną w złocenia: „Introligator nie tylko marginesy złociste dla papieru, ale tyż i na kompatarach, zwyczajnie jak w Paryżu robią i złocą, tak ten rzemieśnik wystawi, id est frontispitio pozłoci i czysto, chędogo zdobi i autora wyrazi złotemi literami"27. Entuzjastyczna analogia wyrobów toruńskich introligatorów z oprawami paryskimi, która wyszła spod pióra Rubinkowskiego, wydaje się jednak zbyt optymistyczna i należy ją traktować raczej jako element reklamy niż opis stanu faktycznego. Skądinąd wiadomo bowiem, że o ile poziom umiejętności warsztatowych toruńskich mistrzów introligatorskich był wysoki, to jednak w XVIII w. nie można mówić o jakichkolwiek innowacjach artystycznych $w$ tej mierze. Wytwory tego cechu oceniane są wyłącznie jako solidne rzemiosło ${ }^{28}$. Rubinkowski donosił często o skomplikowanych targach dotyczących wyceny usług introligatorskich. Podkreślał wielokrotnie taniość ośrodka toruńskiego w porównaniu z kosztami identycznych usług, które trzeba ponieść w Gdańsku. Często także podnosił swoje umiejętności negocjacyjne pozwalające na obniżenie łącznej ceny. Opóźnienia w odesłaniu kolejnych partii książek usprawiedliwiał także niesprzyjającymi warunkami pogodowymi: „słoty codzienne okrutne na przeszkodzie, że introligatorowi [księgi A. K.] wysychać nie chcą"29. W swoich zawiadomieniach Rubinkowski nie skarżył się na poziom usług introligatorskich. Jak zaznaczono powyżej, zachwalał nawet ich duże umiejętności. Miał po temu konkretne podstawy, gdyż statut cechu introligatorów i szkatulników z 1608 r. przewidywał jako majstersztyk wykonanie aż 9 rodzajów różnych opraw książkowych z białej lub brunatnej wyprawionej skóry świńskiej zdobionej złotymi tłoczeniami i okuciami ${ }^{30}$.

W maju 1725 r. Rubinkowski skwitował odbiór dokładnie 485 egzemplarzy książek pomieszczonych w czterech skrzyniach, które przypłynęły Wisłą na statku kierowanym przez szypra w służbie Sieniawskich. Już pobieżna inspekcja wykazała, że brakowało kilku książek, których opis widniał w przesłanym rejestrze. Rubinkowski podejrzewał, zapewne słusznie, że zaginęły one podczas otwierania skrzyń w trakcie rewizji celnej w komorze nieszawskiej. Narzekał również, że rejestr oddanych mu ksiąg jest niedokładny i obiecał własnoręczne ułożenie nowego, w pełni adekwatnego do zawartości skrzyń. Po mniej więcej tygodniu od otrzymania ksiąg informował ich właścicielkę o kulisach swoich negocjacji z toruńskimi introligatorami, podając cenę konserwacji jednego egzemplarza „wielkiego grubego foliału z francuską oprawą" na poziomie 7-8 florenów. Przy czym obiecywał, że dołoży wszelkich starań, aby wynegocjować jeszcze atrakcyjniejszą cenę. Jednocześnie donosił, że wiele woluminów było w opłakanym stanie.

27 BCz, rkps 5933, nr 34518, J. Rubinkowski do E. Sieniawskiej 30 III 1725 r. z Torunia.

28 S. Salmanowicz, Dzieje książki i czytelnictwa..., s. 382.

29 BCz, rkps 5933, nr 34527, J. Rubinkowski do E. Sieniawskiej [przed 12 VIII] 1725 r. z Torunia.

30 S. Herbst, Toruńskie cechy rzemieślnicze. Zarys przeszłości, Toruń 1933, s. 197. 
Zniszczone w znacznym stopniu książki liczono w dziesiątkach egzemplarzy. Wśród wielu „popsowanych” znajdowało się również kilkanaście „pognojonych”. Po oględzinach toruńscy introligatorzy ocenili stan zachowania, kwalifikując około dziesięciu książek jako nienadające się do naprawy. Wyrazili przy tym opinię, że musiały być już gdzieś źle konserwowane. Rubinkowski nie wymienił z nazwiska żadnego z nich. Pisał również: „Introligatorowie nasi zlękli się tych książek, że tak bardzo wielkie foliały i grube, około których wiele pracy"31. Wiadomo, że w latach 20. XVIII w. działało w Toruniu zaledwie trzech mistrzów w cechu introligatorskim. Należeli oni do raczej średniozamożnych mieszczan. W pierwszej dekadzie tego stulecia dużym majątkiem mógł się poszczycić jedynie Samuel Genther ${ }^{32}$.

Pierwsza partia prac konserwacyjnych wypadła bardzo pomyślnie w ocenie toruńskiego poczmistrza, który pisał, że powinny one stanowić wielką ozdobę biblioteki Elżbiety Sieniawskiej. Wśród ksiąg przysłanych do Torunia było także kilkanaście tomów dzieł literatury protestanckiej, zarówno luterańskiej, jak i kalwińskiej. Czekając na decyzję, przedstawiciel katolickiej mniejszości ludności Torunia w radzie miejskiej doradzał poniechanie ich oprawy, sugerując, że szkoda na to wydatkować pieniędzy. W swoim liście Rubinkowski podnosił także szybkie tempo robót introligatorskich oraz własne zasługi w tym względzie zarówno pod względem nakładu pracy, jak i uzyskanej obniżki cenowej u introligatorów. Pisał bowiem, że w ciągu zaledwie czterech dni, z pomocą dwóch podwładnych, sekretarzy pocztowych, przejrzał 120 książek i sporządził ich rejestr, bojąc się fałszerstw ze strony introligatorów. Za radą introligatorów zalecał również oprawienie w jednym tomie kilku „płaskich” książek o mniejszej objętości, argumentując to przewidywaniem ich lepszej prezencji w bibliotece. Odnośnie do cen informował o otrzymaniu znacznego rabatu. Kwoty wynosiły ostatecznie 3, 2 oraz 1 floren i 15 groszy w zależności od wielkości i grubości poszczególnych tomów. Zachwalając toruńskie rzemiosło introligatorskie i własne usługi, pisał, że w Gdańsku podobne zamówienie byłoby dwukrotnie droższe. Zapisy epistolograficzne Rubinkowskiego potwierdzają trudną sytuację materialną introligatorów oraz niewiele realizowanych zamówień, skoro informował, że „nasi rzemieślnicy potrzebniejsi pi[e]niędzy"33. Chociaż nie znamy nazwisk właścicieli warsztatów introligatorskich, którzy dokonywali konserwacji ksiąg na zlecenie Rubinkowskiego, to można określić krąg potencjalnych wykonawców. Mógł do nich należeć wymieniony wyżej Samuel Genther oraz inni czynni wówczas introligatorzy: Jeremiasz Tielich, Kasper Gottfried Ernst, Jan Krzysztof Hoffmann oraz Henryk Rakowski ${ }^{34}$. Wiadoma jest natomiast lokalizacja prac nad konserwacją i oprawą książek, które musiały być przeprowadzane przy ulicach Prostej, Szerokiej bądź Różanej, gdyż tam właśnie zamieszkiwali ówcześnie toruńscy introligatorzy ${ }^{35}$.

\footnotetext{
31 BCz, rkps 5933, nr 34522, J. Rubinkowski do E. Sieniawskiej 27 V 1725 r. z Torunia.

32 K. Mikulski, Pułapka niemożności. Społeczeństwo nowożytnego miasta wobec procesów modernizacyjnych (na przykładzie Torunia w XVII i XVIII wieku), Toruń 2008, s. 168.

${ }_{33}$ BCz, rkps 5933, nr 34522, J. Rubinkowski do E. Sieniawskiej 27 V 1725 r. z Torunia.

34 Z. Mocarski, Książka w Toruniu do roku 1793. Zarys dziejów, [w:] Dzieje Torunia. Praca zbiorowa z okazji 700-lecia miasta, red. K. Tymieniecki, Toruń 1933, s. 458.

35 K. Mikulski, Przestrzeń i społeczeństwo Torunia od końca XIV do początku XVIII wieku, Toruń 1999, s. 289.
} 
Duże zamówienie, obejmujące łącznie około pięciuset tomów, wymagało dłuższego czasu. Już jednak w niecały miesiąc od przyjęcia zlecenia prawie połowa książek była oprawiona. Z poczuciem dobrze spełnionego obowiązku Rubinkowski informował, że 200 tomów jest gotowych. Wydłużenie czasu pracy nad oprawami ksiąg wynikało jednak również z innego faktu, mianowicie związanego z problemami z płynnością finansową. Poczmistrz toruński narzekał, że z winy jednego z szyprów nie może odzyskać 20 czerwonych złotych, które przedpłacił introligatorom. Cały czas zachwalał również Toruń jako prężny, a przy tym tani ośrodek introligatorski. Według niego w Gdańsku miało być nawet cztery razy drożej ${ }^{36}$. W listach powtarzają się błagania Rubinkowskiego o przesłanie pozostałej do zapłacenia kwoty 400 tynfów, gdyż jak argumentował ,introligator bez pi[e] niędzy roboty kończyć nie będzie" ${ }^{37}$. Chwytał się zresztą różnych sposobów do upominania się o kwotę, bez której nie mógł otrzymać książek: „bo jeżeli się jaka stanie szkoda tą prolongacyją to nie będzie wina moja"38.

Według informacji zawartych w listach Rubinkowskiego dokładana statystyka wyników prac toruńskich introligatorów wyglądała następująco: do końca 1725 r. odesłał do Puław 333 księgi, a w 1726 r. 136 woluminów należących „do starej biblioteki". Były to więc zapewne książki z dawnych zbiorów puławskich lub tam przywiezione z innych księgozbiorów. Oprócz tego wysłano jeszcze 41 książek określanych jako „francuskie”. Suma książek, która przeszła przez ręce Rubinkowskiego w ciągu roku (wiosna 1725 r.-wiosna 1726 r.), wynosiła więc z górą ponad pół tysiąca, gdyż w warsztatach introligatorskich pozostawała jeszcze wówczas bliżej nieokreślona liczba ksiąg będących w najgorszym stanie zachowania. W związku z tym Rubinkowski skrupulatnie wyliczał liczbę odesłanych książek: „Suplikuję pamiętać abym potym jakiej cenzury nie popadł i reszta jeszcze jest z[e] staremi [księgami - A. K.], co wszytko razem odeślę"39.

Z wielkiego zamówienia kilkanaście ksiąg było uszkodzonych w znacznym stopniu, a ich zły stan zachowania był tak poważny, że nie nadawały się już do konserwacji, wskutek czego zaniechano kompletnie prac nad ich renowacją i odesłano w stanie pierwotnym razem z oprawionymi egzemplarzami: „Wszytko się w kawałki pada, pożal się Boże tak główne księgi, że tak w złej konserwacyi były, drogo by teraz takowe kosztowały i nie wiem skąd by takowe dostać, których opracować niepodobna i na nie koszta łożyć"40. Ostatecznie wiosną 1726 r. Rubinkowski wysłał do Puław 138 sztuk „ksiąg dawnych”. Osobno zostały zapakowane książki w języku francuskim, chociaż nie wymienił żadnych tytułów. Najbardziej zniszczone książki pozostawił jeszcze w Toruniu, mając nadzieję na dobicie targu z introligatorami odnośnie do ich oprawy. Kupował w tym celu skórę i papier, oczekując zwrotu pieniędzy od Elżbiety Sieniawskiej ${ }^{41}$.

\footnotetext{
${ }^{36}$ BCz, rkps 5933, nr 34523, J. Rubinkowski do E. Sieniawskiej 10 VI 1725 r. z Torunia.

37 BCz, rkps 5933, nr 34531, J. Rubinkowski do E. Sieniawskiej 30 IX 1725 r. z Torunia.

${ }_{38}$ BCz, rkps 5933, nr 34534, J. Rubinkowski do E. Sieniawskiej 11 XI 1725 r. z Torunia.

39 BCz, rkps 5933, nr 34541, J. Rubinkowski do E. Sieniawskiej czerwiec 1726 r. z Torunia.

40 BCz, rkps 5933, nr 34535, J. Rubinkowski do E. Sieniawskiej 3 II 1726 r. z Torunia.

${ }^{41}$ BCz, rkps 5933, nr 34411, J. Rubinkowski do E. Sieniawskiej 12 V 1726 r. z Torunia.
} 
Wiosną 1726 r. do Torunia przybywały kolejne transporty książek do oprawy. Ich liczba była zdecydowanie mniejsza niż w poprzednim roku. Były to już zapewne pojedyncze tomy, ale Rubinkowski musiał się tłumaczyć z opóźnień problemami technicznymi związanymi z koniecznością zamawiania specjalnych ponadwymiarowych kawałków skóry, które wydłużały pracę introligatora: „ponieważ grube, wielkie są foliały, że umyślnie wielkich skór dobierać ze Gdańska zapisał". Kupiecki zmysł Rubinkowskiego podsuwał mu swoisty rachunek korzyści intelektualno-ekonomicznych, w myśl którego doradzał zaniechanie konserwacji ksiąg najbardziej „zgniłych i zepsowanych”. Zamiast tego sugerował raczej zakup pozycji bibliograficznych nowych autorów, łłumacząc, że zawierają one cały starszy dorobek literacko-naukowy, ale znacznie „lepszym stylem i manierą drukowanych”. Takie rozwiązanie polecał, zaręczając, że w Toruniu „by dobrał tak wiele nowych, głównych autorów kto by tego pretendował"42.

Poczmistrz toruński przesyłał także wykazy ksiąg dostępnych u bibliofili toruńskich, zwracając uwagę na tytuły, których brakowało w bibliotece Sieniawskiej: „są niektóre polskie autory, osobliwie kroniki piękne”43. Wiosną 1725 r. Rubinkowski poczynił też Sieniawskiej pierwsze większe oferty w kwestii zakupu książek. Informując o postępach prac introligatorów, doradzał dokupić kilka nowości wydawniczych w celu upiększenia biblioteki puławskiej Sieniawskich. Miały one pochodzić z ostatnich woluminów wyprzedanego pośmiertnie księgozbioru wojewody chełmińskiego, którym wówczas był Jakub Zygmunt Rybiński (zmarł on jednak dopiero 16 grudnia 1725 r. $^{44}$, a zatem ponad pół roku po dacie widniejącej na liście Rubinkowskiego). Wzmianka ta jest o tyle ciekawa, że dotychczas aukcja książek z biblioteki Rybińskiego nie została odnotowana w zestawieniu toruńskich licytacji księgarskich w XVIII w. Przedmiotem właściwie wszystkich znanych dotąd toruńskich aukcji były bowiem biblioteki mieszczan toruńskich ${ }^{45}$. Najbardziej godne uwagi wydało mu się w tej kolekcji dzieło autorstwa szwedzkiego i brandenburskiego historiografa Samuela Puffendorfa, zatytułowane De rebus a Carolo Gustavo Sueciae rege gestis, wydane w 1696 r. Zachwalał zarówno jego treść, jak i wspaniałe ryciny miedziorytnicze: „Bardzo curiosa, wielkie w której są pakta oliwskie i całej Polskiej deskrypcyje, wojna z Polakami, wszystkie miasta, miasteczka jakie tej wojny były krótko namieniając bardzo piękne w niej kuriosa i kopersztychy". Reklamował również dzieła słynnego barokowego filozofa przyrody Athansiusa Kirchera, a szczególnie księgę opisującą Indie ${ }^{46}$. Jeśli rzeczywiście była tu mowa o dziele Kirchera, to do notatek Rubinkowskiego, zazwyczaj bardzo skrupulatnego w oddaniu nazwisk autorów i tytułów książek, wkradła się drobna pomyłka, gdyż faktycznie Kircher napisał kompendium wiedzy o kraju azjatyckim, lecz były to Chiny: China monumentis qua sacris, qua profanis, nec non variis

\footnotetext{
${ }^{42}$ BCz, rkps 5933, nr 34540, J. Rubinkowski do E. Sieniawskiej 5 V 1726 r. z Torunia.

${ }_{43}$ BCz, rkps 5933, nr 34529, J. Rubinkowski do E. Sieniawskiej 26 VIII 1725 r. z Torunia.

44 Urzędnicy Prus Królewskich XV-XVIII wieku. Spisy, opr. K. Mikulski, Wrocław-Warszawa-Kraków 1990, s. 78.

45 I. Imańska, Toruńskie aukcje książek w XVIII w., Toruń 2007, s. 22-23.

${ }^{46}$ BCz, rkps 5933, nr 34522, J. Rubinkowski do E. Sieniawskiej 27 V 1725 r. z Torunia.
} 
naturae \& artis spectaculae aliarumque rerum memorabilium argumentis illustrata, Amsterdam 1667.

Wydaje się, że głównym zadaniem Rubinkowskiego miało być pośrednictwo w procesie restauracji ksiąg do biblioteki puławskiej. Większość informacji dotyczących książek, zawartych w jego listach, sprowadza się do kwestii techniczno-praktycznych związanych z introligatorstwem. Dopiero w drugiej kolejności poczmistrz toruński zamieszczał zawiadomienia o zbliżających się aukcjach książek w Toruniu. Nieprzypadkowo Rubinkowski stał się, może po gdańszczanach, najważniejszym z dostarczycieli książek do bibliotek Elżbiety Sieniawskiej. Taką rangę zapewniła mu ważna rola Torunia jako centrum handlu księgarskiego w wymiarze nie tylko regionalnym, lecz także krajowym. Było to bowiem drugie po Gdańsku miasto w Rzeczypospolitej, w którym zaczęto organizować aukcje książek ${ }^{47}$. Rubinkowski sam był zresztą stałym bywalcem toruńskich aukcji. Brał udział w licytacjach kolejnych bibliotek toruńskich bibliofilów: Schultza (1718), Oloffa (1722), Linderhausena (1725) i Laurera (1732) ${ }^{48}$.

Wykorzystując swoje doświadczenia, z dużym wyprzedzeniem informował o jednej z największych aukcji książek tego czasu, pochodzących z biblioteki Gerharda Thomasa, która odbyła się 4 marca 1726 r.: „Po zmarłym burmistrzu Gierat Tomaszu główną bibliotekę przedawać tu na ausrufie będą za tydzień". Donosił również wówczas, że będzie można tam kupić najważniejsze i najbardziej cenione tytuły ówczesnej literatury polskiej i europejskiej. W związku z tym prosił o przesłanie większej kwoty pieniędzy w złocie, aby mógł stanąć bezpośrednio do aukcji, gdyż „z pierwszej ręki dostanie pobożnie, bo z drugiej ręki ani się dokupić nie można"49. Działania Rubinkowskiego w tej materii należy ocenić jako wyważone i przemyślane zabiegi doświadczonego bibliofila doskonale znającego drukowane katalogi aukcji, który szukał okazji powiększenia własnej biblioteki, ale także informował znajomych miłośników ksiąg oraz realizował zlecenia zakupu książek dla innych osób ${ }^{50}$.

Jeszcze wcześniej - latem 1725 r. anonsował tytuły kilku książek, które nabył w Toruniu. Były to dzieła ojca Elżbiety Sieniawskiej, znanego polskiego pisarza barokowego, marszałka wielkiego koronnego Stanisława Herakliusza Lubomirskiego. Rubinkowski odnotował oddanie do oprawy introligatorowi czterech książek tego autora. Wśród nich znajdowały się: „Adverbia Moralia”, Tobiasz Wyzwolony, dzieło inspirowane tematyką biblijną powstałe w latach 60. XVII w. i wydane drukiem w 1683 r. oraz De Vanitate Consiliorum ${ }^{51}$. Być może stan i wygląd po konserwacji i oprawie egzemplarza Tobiasza Wyzwolonego był ciągle wysoce niezadowalający, skoro zaledwie miesiąc później prosił Sieniawską o zakupienie w Warszawie „pro memoria do biblioteki” innego woluminu tego dzieła, gdyż tam

\footnotetext{
47 I. Imańska, Per medium auctionis. Aukcje książek w Rzeczypospolitej (XVII-XVIII w.), Toruń 2013, s. 78-79.

48 K. Maliszewski, Jakub Kazimierz Rubinkowski..., s. 103-104.

49 BCz, rkps 5933, nr 34532, J. Rubinkowski do E. Sieniawskiej 21 X 1725 r. z Torunia.

50 I. Imańska, Toruńskie aukcje książek w XVIII w...., s. 104.

51 BCz, rkps 5933, nr 34528, J. Rubinkowski do E. Sieniawskiej 12 VIII 1725 r. z Torunia.
} 
miał być on znacznie tańszy niż w Toruniu: „tu tylko się jedna znajduje i nie chcą jej dać od talera bitego"52.

Wysokie ceny dzieła Lubomirskiego w Toruniu świadczyły zapewne o małej podaży dostępnych egzemplarzy. Jest to sytuacja dość symptomatyczna, gdyż to właśnie w Toruniu od początku XVIII w. ukazywały się książki tego autora nakładem spółki wydawniczej księgarza Jana Ludwika Nicolai oraz drukarza i nakładcy Jana Chrystiana Laurera ${ }^{53}$. Warto również nadmienić, że także w Toruniu ukazało się polskie tłumaczenie innego dzieła Lubomirskiego De Vanitate Consiliorum, wydane pod tytułem Próżność y prawdy rady ${ }^{54}$. W Bibliotece Narodowej w Warszawie zachował się unikalny egzemplarz De Vanitate Consiliorum, wydrukowany w 1700 r., w którym na rewersie karty tytułowej widnieje odręczna notatka, że pochodzi on z prywatnego księgozbioru Rubinkowskiego ${ }^{55}$. Fakt ten zdaje się potwierdzać tezę, że poczmistrz toruński nie stosował ekslibrisów do znakowania swoich ksiąg, podobnie zresztą jak i inni toruńscy bibliofile w tym czasie $^{56}$. Rubinkowski musiał dobrze znać toruńskie katalogi wydawnicze, bowiem w listach stosował fachową terminologię księgarską, używając określeń in folio, in quarto, in octavo, co było zapewne efektem częstej lektury katalogów książek, w których stosowano identyczny podział ksiąg z poszczególnych bibliotek czy wydawnictw na trzy grupy według formatów. Było to podstawowe kryterium podziału książek, znacznie częściej spotykane niż znany dziś układ alfabetyczny czy chronologiczny ${ }^{57}$.

Książek dla Sieniawskiej Rubinkowski szukał nie tylko w Toruniu, choć jego rodzinne miasto było głównym źródłem nabytków bibliotecznych. Równolegle pozyskiwał pojedyncze tomy również w innych ośrodkach. Z Warmii („Brądzberku” - jak pisał) przywieziono mu zakupiony egzemplarz wydrukowanej w Braniewie (1725) kroniki dziejów prowincji Prus autorstwa Jana Leo, katolickiego duchownego i historyka, żyjącego i tworzącego na przełomie XVI i XVII w. Rękopis kroniki Historia Prussiae, ukończonej w 1631 r., musiał czekać na druk prawie całe stulecie. Wydanie dokonane staraniem kanoników kolegiaty w Dobrym Mieście cieszyło się jednak dużym powodzeniem w kręgach katolickich i było jeszcze dwukrotnie wznawiane (1726 i 1728) ${ }^{58}$. Książkę tę Rubinkowski traktował jako potencjalnie skuteczny oręż walki ideologiczno-konfesyjnej w toczącym się wówczas konflikcie z mocarstwami innowierczymi, będącym reperkusją po finale tzw. tumultu toruńskiego: „bardzo piękną Historyją Pruską, świżej edycyi, która do teraźniejszej tranzakcyi z dysydentami na defensę bardzo potrzebna". Obiecał przesłać ją do Warszawy jako pomoc i ważną polityczną lekturę dla hetmana Adama Mikołaja

\footnotetext{
${ }^{52}$ BCz, rkps 2707, s. 725, J. Rubinkowski do E. Sieniawskiej 16 IX 1725 r. z Torunia.

53 A. Tujakowski, Z dziejów drukarstwa i piśmiennictwa na Pomorzu. 400 lat drukarstwa w Toruniu (1569-1969), Toruń 1970, s. 75-77.

${ }^{54}$ S. Salmonowicz, Toruńskie gimnazjum akademickie w latach 1681-1817. Studium z dziejów nauki i oświaty, Bydgoszcz 1973, s. 142.

55 K. Maliszewski, Jakub Kazimierz Rubinkowski..., s. 105

56 S. Salmonowicz, Dzieje książki i czytelnictwa..., s. 394.

57 B. Serczykowa, Księgozbiór lekarza toruńskiego Wacława Duroscha z drugiej połowy XVII wieku, Zeszyty Naukowe UMK w Toruniu, 1971, Nauki Humanistyczno-Społeczne, z. 39, Nauka o Książce VI, s. 7-14.

58 Z. Nowak, Leo Jan (1572-1635), [w:] PSB, t. 17, Wrocław 1972, s. 66.
} 
Sieniawskiego, uważając, że może być przydatna „JO Jm Panu krakowskiemu, jako i JW. JmP wojewodzie Potockiemu na gaszenie imprezy dysydenckiej ${ }^{59}$.

Ważne miejsce wśród książek poszukiwanych dla Sieniawskiej zajmowały dzieła o tematyce historycznej. Obok wspomnianej wcześniej pracy kronikarskiej Jana Leo Rubinkowski nabył również i przesłał wiosną 1726 r. dwa tomy prac Jana Długosza wydane w Lipsku w 1722 r. ${ }^{60}$ Już po zakończeniu korespondencji z Sieniawską, i de facto po jej śmierci, Rubinkowski kontynuował swoje pasje historyczne, zdobywając rzadkie i ciekawe książki. W 1735 r. przesłał ordynatowi Pawłowi Sanguszce, jak sam pisał, „ciekawy projekt”, którym była „książka wierszem polskim drukowana", czyli niedawno wydany opis ucieczki króla Stanisława Leszczyńskiego z Gdańska (1734), który jednak cenzura zatrzymała w Warszawie. Wobec zaistniałej sytuacji Rubinkowski prosił adresata o szybką interwencję w kwestii oddania zarekwirowanego egzemplarza z opisem „salwowania się ze Gdańska do Kwidzyna Stanisława Leszczyńskiego"61.

Jako wytrawny bibliofil i znawca literatury Rubinkowski nie tylko kupował książki dla Sieniawskiej, lecz także dzielił się ekscytującymi wrażeniami intelektualnymi z lektury ksiąg. W jednym $z$ listów zachwalał teksty dwóch świetnie ilustrowanych miedziorytami dzieł toruńskiego historyka Krzysztofa Hartknocha Respublica Polonica duobus libris illustrata oraz Alt- und Neues Preussen ${ }^{62}$. W podzięce za otrzymane poparcie starał się rewanżować Elżbiecie Sieniawskiej drobnymi prezentami: „Dla ozdoby większej i przysługi pańskiej WXMości Dobrodziejki ja ex parte sua przydam konterfekt owego pierwszego matematyka na świecie Kopernika i księgę i głowy stare rzymskie do biblioteki należące"63. Być może składając tę obietnicę, miał na myśli słynne dzieło Mikołaja Kopernika będące fundamentem nowożytnej teorii heliocentrycznej.

Proces poszukiwania i kupna książek dla Elżbiety Sieniawskiej skupiał się głównie na obserwowaniu licytacji aukcyjnych organizowanych w Toruniu oraz zakupach u lokalnych bibliofilów w ich prywatnych księgozbiorach. Rubinkowski sam często doradzał kupno niektórych tytułów, które akurat można było nabyć po okazyjnych cenach. Jednak głównym wyznacznikiem jego księgarskich poszukiwań były rejestry ksiąg zestawianych zgodnie z życzeniami Sieniawskiej i przysyłane do Torunia. Rubinkowski nie wahał się narzekać na mało fachowy sposób sporządzania katalogów książek wybranych do zakupu: „Waryjacyja wielka w przysłanym regestrze. Niektóre księgi pisano, że są in folio, ale autory były i znalazły się in 4to, vel in $8 v o$ i innych w nim errorów kupa". Zastrzegał jednak, że kupował księgi, które były zapisane w otrzymanym rejestrze i w tym fakcie pokładał nadzieję, iż adresatka będzie zadowolona z tego księgarskiego nabytku. Wysyłając zaś ostatnią wzmiankowaną w listach partię zakupionych przez siebie

59 BCz 2747, s. 420-421, J. Rubinkowski do E. Sieniawskiej 19 VIII 1725 r. z Torunia.

60 K. Maliszewski, Jakub Kazimierz Rubinkowski..., s. 103. (Informacja zawarta w liście z 7 IV 1726 r.).

61 Archiwum Narodowe w Krakowie, oddział I, Archiwum Sanguszków, teki korespondencji 8, J. Rubinkowski do P. Sanguszki 20 VIII 1735 r. z Torunia, s. 617.

62 K. Maliszewski, Jakub Kazimierz Rubinkowski..., s. 105. (Informacja zawarta w liście z 27 XII 1723 r.).

63 BCz, rkps 5933, nr 34547, J. Rubinkowski do E. Sieniawskiej 10 XI 1726 r. z Torunia. 
książek, załączył do niej również obiecane wcześniej kopernikana: „W tej skrzyni pod księgami są 3 głowy malowane stare rzymskie i konterfekt Kopernika, wielkiego i pierwszego na świecie matematyka, który był natione Toruńczanin, kanonik warmiński"64. W stosunku do wcześniejszych deklaracji można podejrzewać, że ostatecznie zabrakło egzemplarza O obrotach sfer niebieskich.

Rubinkowski prowadził stałą kwerendę dostępnych w sprzedaży książek, poszukując także okazyjnych egzemplarzy, które nie znalazły nabywców podczas aukcji lub były do kupienia z wolnej stopy. Przykładowo w miesiąc po wzmiankowanej już w tym artykule licytacji biblioteki Gerharda Thomasa przeglądał pozostałe egzemplarze i szczególnie zainteresował się trzema dziełami niderlandzkiego humanisty Justusa Lipsiusa, a wśród nich najpewniej zbiorem jego listów oraz słynną Polityką. Wzmiankował wtedy również dwie inne zakupione książki, które umieścił w swoich listach pod dość zawiłymi opisami: Mirabilis mundi oeconomia Zahna oraz Kronikę od stworzenia świata Nauklera ${ }^{65}$. Pierwsze z wymienionych dzieł to znane w Europie kompendium matematyczne i przyrodnicze autorstwa Johanna Zahna, niemieckiego mnicha-erudyty z zakonu premonstratensów, zatytułowane Specula physico-mathematico-historica notabilium ac mirabilium sciendorum in qua mundi mirabilis oeconomia, wydane w Norymberdze w 1696 r. Znajomość tego opracowania jest dowodem na scjentystycznie zorientowane zainteresowania Rubinkowskiego. Intrygujący jest również drugi tytuł wymieniony w jego korespondencji odnoszący się do poczytnej XVI-wiecznej kroniki niemieckiego humanisty epoki renesansu Johannesa Nauclerusa (Nauklera), która została wydana pośmiertnie w 1516 r. pod tytułem Memorabilium omnis aetatis et omnium gentium chronici commentarii. Badacze ideologii sarmatyzmu akcentują ważną rolę tego autora i dzieła w rozwoju jednej z wersji tego prądu ideowego zastosowanego jako narzędzie do ustalenia genealogii etnicznej Polaków. Narracja kroniki Nauklera utożsamiała Polskę, której mieszkańcy uważali za swoich protoplastów antycznych Sarmatów, z Wandalią będącą częścią Germanii i pozostającą pod władzą legendarnego Tuskona ${ }^{66}$. W tym ujęciu ciekawe są motywy anonsowania Sieniawskiej zakupu dzieła Nauklera przez Rubinkowskiego, które być może było przez niego traktowane jako próba pradziejowego uzasadnienia symbiozy i koegzystencji narodowego żywiołu polskiego i niemieckiego w Toruniu i szerzej w Prusach Królewskich. Wyszczególnienie tytułów i autorów tych ksiąg mogło też być z jego strony zwykłą próbą podkreślenia ich znacznej wartości, czym starał się zdyskontować fakt zakupu zaledwie czterech ksiąg z powodu ogromnego zainteresowania uczestników aukcji oraz wysokich cen poszczególnych woluminów: „ledwie się można było docisnąć bo tam po sto i więcej talerów płacono księgi” ${ }^{67}$.

\footnotetext{
${ }_{64}$ BCz, rkps 5933, nr 34549, J. Rubinkowski do E. Sieniawskiej 17 XII 1726 r. z Torunia.

65 K. Maliszewski, Jakub Kazimierz Rubinkowski..., S. 104-105. (Informacja zawarta w liście z 7 IV 1726 r.).

66 S. Cynarski, Sarmatyzm - ideologia i styl życia, [w:] Polska XVII w., red. J. Tazbir, Warszawa 1974, s. 222

${ }_{67}$ BCz, rkps 5933, nr 34538, J. Rubinkowski do E. Sieniawskiej 7 IV 1726 r. z Torunia.
} 
Kolejne listy wskazują, że w zasadzie do końca okresu korespondencji z Elżbietą Sieniawską (1726), czyli właściwie do momentu śmierci jej męża hetmana Adama Mikołaja Sieniawskiego i krótko po tym fakcie, poczmistrz żywo interesował się losami kolekcji księgarskiej pozostałej po Gerhardzie Thomasie. Wysyłał Sieniawskiej katalogi książek ciągle dostępnych w ofercie oraz ponaglał w kwestii wyboru konkretnych tytułów i przesłania pieniędzy na zakup książek. Ostatecznie zakupił jedno z dzieł Lipsiusa, a najpewniej był to właśnie egzemplarz wspomnianej powyżej Polityki, sądząc z dużej objętości tej księgi, która zmusiła go do podjęcia dość osobliwych zabiegów: „Lipsiusza com przykupił dla WXMci musiałem go dać na 4 księgi in folio rozdzielić dla wielkości ciężaru i lepszej proporcyi" ${ }^{\prime \prime}$.

Stosunkowo krótko trwające relacje księgarskie pomiędzy Jakubem Kazimierzem Rubinkowskim a Elżbietą Sieniawską, których największe natężenie przypadło przede wszystkim na lata 1725-1726, z kilkoma wcześniejszymi epizodami, były wypadkową roli i znaczenia poczmistrza toruńskiego oraz rangi samego miasta jako ważnego ośrodka księgarskiego w Rzeczypospolitej, a także bieżących potrzeb konserwatorskich i kolekcjonerskich Elżbiety Sieniawskiej. Pośrednictwo Rubinkowskiego miało istotne znaczenie dla organizacji biblioteki pałacowej w Puławach oraz nieco mniejszą dla pozostałych księgozbiorów pozostających w rękach Sieniawskiej i jej męża. Dzięki szerokim kontaktom oraz dostępowi do najświeższych informacji i druków był on cennym korespondentem i faktorem potrafiącym w umiejętny, szybki i skuteczny sposób realizować zlecenia zakupu książek. W tym procesie wzbogacania księgozbioru puławskiego niezwykle istotna była również wysoka pozycja Torunia na polskim rynku księgarskim gwarantująca swobodny dostęp do wielu ważnych i rzadkich tytułów literatury współczesnej oraz dawnej. Także w kwestii konserwacji książek nadsyłanych z Puław Rubinkowski, jako urzędnik pocztowy odpowiedzialny za spedycję listów, gazet i książek, okazał się niezwykle przydatny, zapewniając realizację dużego zlecenia obejmującego renowację kilkuset ksiąg.

${ }^{68}$ BCz, rkps 5933, nr 34411, J. Rubinkowski do E. Sieniawskiej 12 V 1726 r. z Torunia. 


\section{Adam Kucharski}

Institute of History and Archival Science, Nicolaus Copernicus University in Toruń e-mail: akr88@umk.pl

Dr hab. Adam Kucharski is a academic researcher at the Institute of History and Archive Studies of Nicolaus Copernicus University in Toruń. He deals with the topic of travelling in the Early Modern period, the mobility of Polish society in the $16^{\text {th }}-18^{\text {th }}$ centuries, the Old-Polish worldview along with Polish-Spanish cultural contacts in the Early Modern period. His most important publications include: Hiszpania i Hiszpanie w relacjach Polaków (Warszawa 2007) and Theatrum peregrinandi. Poznawcze aspekty staropolskich podróży w epoce późnego baroku (Toruń 2013). He has cooperated with the Museum of the Palace of King John III in Wilanów (within the project "Silva Rerum") and the editorial office of "Wiadomości Historyczne".

\section{Jakub Kazimierz Rubinkowski as a go-between in the preservation and purchase of books for Elżbieta Sieniawska at the end of the first quarter of the $18^{\text {th }}$ century}

eywords: Jakub Rubinkowski, Elżbieta Sieniawska, book, bookbindery, Toruń

ummary: The multidimensional activity of Torun's town councillor and royal postmaster Jakub Kazimierz Rubinkowski mainly concerned the running of an information agency dealing with editing and distributing manuscripts . An important aspect of his cultural activity became his role as an agent in book-binding services and the purchase of books for the wife of the Grand Crown Hetman and Castellan of Cracow - Elżbieta Sieniawska. Rubinkowski, a noblewoman, a Baroque erudite and a bibliophile - he was an ideal candidate to carry out such tasks. His work was facilitated by the fact that Torun enjoyed a strong position on the Polish bookselling market, which guaranteed the possibility to purchase both Polish and foreign books which were in demand.

The bookseller's search query included the works of Sieniawska's father - Stanisław Herakliusz Lubomirski), other Polish authors (also from the territory of Royal Prussia) along with the classics of the early modern European literature. Equally important was the fact that Rubinkowski had a direct contact with Torun's guild of book-binding masters, which helped Sieniawska to preserve and renovate the books, which mostly came from her library in Puławy. Rubinkowski, particularly in the years 1725-1726, informed about the upcoming auctions of books organised in Toruń, received books sent in ships from Puławy and organised the transport of the purchased and renovated volumes. Within two years he participated in the purchase of a few hundreds of books, which made him one of the leading book-selling agents of the time of the Polish-Lithuanian Commonwealth. 


\section{Adam Kucharski}

Institut für Geschichte und Archivwisenschaft, Nikolaus Kopernikus Universität in Toruń e-mail: akr88@umk.pl

Dr. hab. Adam Kucharski ist wissenschaftlicher Mitarbeiter am Institut für Geschichte und Archivwesen an der Nikolaus-Kopernikus-Universität in Thorn. Er beschäftigt sich mit Reisen in der Neuzeit, Mobilität der altpolnischen Gesellschaft, ästhetischer Sensibilität der polnischen Gesellschaft zwischen dem 16. und 18. Jahrhundert, altpolnischem Weltbild und polnisch-spanischen Kulturkontakten in der Neuzeit. Zu seinen wichtigeren Publikationen gehören: Hiszpania i Hiszpanie w relacjach Polaków [Spanien und Spanier in Berichten von Polen] (Warszawa 2007) und Theatrum peregrinandi. Poznawcze aspekty staropolskich podróży w epoce późnego baroku [Theatrum peregrinandi. Altpolnische Reisen im Spätbarock und deren Aspekte der Erkenntnis] (Toruń 2013). Im Rahmen der Popularisierung der Wissenschaft arbeitete er mit dem Museum des Schlosses des Königs Johannes III. in Wilanów (Projekt „Silva rerum”) sowie der Redaktion der Zeitschrift „Wiadomości Historyczne” zusammen.

\section{Vermittlung von Jakub Kazimierz Rubinkowski bei der Buchkonservierung und -ankauf für Elżbieta Sieniawska Ende des ersten Viertels des 18. Jahrhunderts}

chlüsselwörter: Jakub Rubinkowski, Elżbieta Sieniawska, Buch, Buchbinderei, Thorn

usammenfasung: Die vielschichtige Tätigkeit des Thorner Ratsherrn und Königlichen Postmeisters Jakub Kazimierz Rubinkowski konzentrierte sich hauptsächlich auf die Leitung einer Informationsagentur, die sich mit Redaktion und Kolportage handschriftlicher Presse beschäftigte. Zu einem wichtigen Aspekt seiner kultureller Tätigkeit wurde auch die Vermittlung von Dienstleistungen im Bereich der Buchbinderei und beim Ankauf von Büchern für Elżbieta Sieniawska, Gattin des Großhetmans der polnischen Krone und Krakauer Kastellans. Rubinkowski, ein Adliger und zugleich Gelehrter sowie leidenschaftlicher Buchliebhaber der Barockzeit, erschien als ein idealer Kandidat für die Realisierung von solchen Aufgaben. Über seine Nützlichkeit entschied auch die starke Position Thorns auf dem polnischen Büchermarkt, wo gefragte Werke sowohl polnischer als auch ausländischer Autoren leichter erworben werden konnten. Die Recherche erfasste Werke des Vaters von Sieniawska, Stanisław Herakliusz Lubomirski sowie anderer polnischer Autoren (auch aus dem Gebiet des Königlichen Preußen) und Klassiker der neuzeitlichen europäischen Literatur. Ein großer Vorteil von Rubinkowski bestand auch in seinen direkten Kontakten zur Thorner Zunft der Buchbinder, wodurch Sieniawska auf eine professionelle Konservation und Restaurierung von Büchern, die hauptsächlich aus ihrer Bibliothek in Puławy stammten, rechnen konnte. Insbesondere in den Jahren 1725-1726 hat Rubinkowski mehrmals und immer sehr detailliert über die kommenden Buchauktionen in Thorn informiert, aus Puławy mit Schiffen transportierte Bände in Empfang genommen und den Transport von neu erworbenen bzw. restaurierten Volumina organisiert. Innerhalb von nur zwei Jahren vermittelte Rubinkowski im Falle von einigen Hunderten von Büchern, was inn zu einem der führenden Buchagenten seiner Zeit in Rzeczpospolita kürte. 